\title{
Electroanalytical Investigations on Formation of Thallium(I) Molybdates as a Function of pH
}

\author{
Shiva Prasad ${ }^{*, a}$, André L.F. Brito ${ }^{a}$, Valderí D. Leite ${ }^{b}$ and Antônio G. Souza ${ }^{c}$ \\ ${ }^{a}$ Departamento de Engenharia Química, Centro de Ciências e Tecnologia, Universidade Federal da Paraíba, \\ CP 10108, 58109-970 Campina Grande - PB, Brazil \\ ${ }^{b}$ Departamento de Química, CCT, Universidade Estadual da Paraíba, 58100-000 Campina Grande - PB, Brazil \\ ${ }^{c}$ Departamento de Química, CCEN, Universidade Federal da Paraíba, 58059-900 João Pessoa - PB, Brazil
}

\begin{abstract}
A formação de molibdatos de tálio obtidos a partir de interação de nitrato de tálio(I) e molibdato de sódio nos valores específicos do pH 7,6; 5,5 e 4,1 foi estudada através de técnicas eletrométricas envolvendo titulações potenciométricas e condutométricas, em meios aquoso e alcoólico, com cada reagente usado alternadamente como titulante. As inflexões e degraus bem definidos nas curvas de titulação fornecem evidências incontestáveis sobre a formação de molibdatos normal- $\mathrm{Tl}_{2} \mathrm{O}_{\mathrm{MoO}}$, para- $3 \mathrm{Tl}_{2} \mathrm{O} .7 \mathrm{MoO}_{3}$ e octa- $2 \mathrm{Tl}_{2} \mathrm{O} .8 \mathrm{MoO}_{3}$ de tálio(I) nas vizinhanças de $\mathrm{pH} 6,8 ; 5,9$ e 5,2 respectivamente. Estudos analíticos também foram realizados sobre os precipitados de molibdatos de tálio(I) confirmando os resultados obtidos pelas técnicas eletrométricas.
\end{abstract}

The formation of thallium(I) molybdates obtained by interaction of thallium(I) nitrate and sodium molybdate at specific pH levels 7.6, 5.5 and 4.1 has been studied by electrometric techniques involving potentiometric and conductometric titrations, in aqueous and alcoholic media using each reagent as titrant. Well defined breaks and inflections in the titration curves provide cogent evidence for formation of thallium normal $-\mathrm{Tl}_{2} \mathrm{O} . \mathrm{MoO}_{3}$, para- $3 \mathrm{Tl}_{2} \mathrm{O} .7 \mathrm{MoO}_{3}$ and octa $-2 \mathrm{Tl}_{2} \mathrm{O} .8 \mathrm{MoO}_{3}$ molybdates in the vicinity of $\mathrm{pH} 6.8,5.9$ and 5.2, respectively. Analytical investigations of the precipitates of thallium(I) molybdates have also been carried out, which substantiate the results of the electrometric study.

Keywords: molybdates, thallium(I) molybdates, electrometry

\section{Introduction}

The chemistry of molybdenum is very prominent in both biological and industrial systems. ${ }^{1,2}$ Recent studies have shown that certain molybdates have antiviral, including anti-AIDS, and antitumor activity. ${ }^{3}$ Although a large number of studies have been done in the field of molybdate chemistry, the chemical state of isopolymolybdates, obtained on acidification of a molybdate solution, is not well understood because of the complexity in polymerization. Jander et al. claimed existence of $\mathrm{Mo}_{3} \mathrm{O}_{11}{ }^{4-}, \mathrm{HMo}_{3} \mathrm{O}_{11}{ }^{3-}, \mathrm{HMo}_{6} \mathrm{O}_{21}{ }^{5-}, \mathrm{H}_{2} \mathrm{Mo}_{6} \mathrm{O}_{21}{ }^{4-}$, $\mathrm{H}_{3} \mathrm{Mo}_{6} \mathrm{O}_{21}{ }^{3-}, \mathrm{H}_{7} \mathrm{Mo}_{12} \mathrm{O}_{41}{ }^{3-}, \mathrm{H}_{7} \mathrm{Mo}_{24} \mathrm{O}_{78}{ }^{5-}$ and $\mathrm{H}_{9} \mathrm{Mo}_{24} \mathrm{O}_{78}{ }^{3-}$ from diffusion and optical experiments. ${ }^{4}$ Bye claimed the existence of $\mathrm{Mo}_{7} \mathrm{O}_{24}{ }^{6-}, \mathrm{Mo}_{6} \mathrm{O}_{20}{ }^{4-}, \mathrm{Mo}_{4} \mathrm{O}_{13}{ }^{2-}$ and $\mathrm{HMo}_{6} \mathrm{O}_{20}{ }^{3-}$ by cryoscopic study. ${ }^{5}$ In 1959 , Sasaki et al. deduced from

* e-mail: prasad@deq.ufpb.br potentiometry that the main complex formed is $\mathrm{Mo}_{7} \mathrm{O}_{24}{ }^{6-6}$ Subsequently mathematical analysis was applied to potentiometric equilibrium curves, and Sasaki et al. claimed the existence of $\mathrm{Mo}_{7} \mathrm{O}_{24}{ }^{6-}, \mathrm{HMo}_{7} \mathrm{O}_{24}{ }^{5-}, \mathrm{H}_{2} \mathrm{Mo}_{7} \mathrm{O}_{24}{ }^{4-}$ and $\mathrm{H}_{3} \mathrm{Mo}_{7} \mathrm{O}_{24}{ }^{3-}$ up to a value of $\mathrm{Z}$ (average number of $\mathrm{H}^{+}$ being consumed by $\mathrm{MoO}_{4}{ }^{2-}$ ) of around 1.4. ${ }^{7,8}$ Aveston et $a l .{ }^{9}$ by centrifuge data could only tell that in the range studied, the species probably contain more than 6 and less than 9 Mo atoms. Sasaki et al. proposed the presence of large isopolymolybdate anions of the order of 20 Mo in the solution of $\mathrm{Z}>1.5$. $^{7}$ Numerous species such as $\mathrm{HMoO}_{4}^{-}$, $\mathrm{H}_{2} \mathrm{MoO}_{4}, \mathrm{Mo}_{2} \mathrm{O}_{7}{ }^{2-}, \mathrm{HMo}_{3} \mathrm{O}_{11}{ }^{3-}, \mathrm{Mo}_{6} \mathrm{O}_{19}{ }^{2-}, \mathrm{Mo}_{7} \mathrm{O}_{24}{ }^{6-}$, $\mathrm{HMoO}_{24}{ }^{5-}, \mathrm{H}_{2} \mathrm{Mo}_{7} \mathrm{O}_{24}{ }^{4-}, \mathrm{Mo}_{8} \mathrm{O}_{26}{ }^{4-}, \mathrm{HMo}_{8} \mathrm{O}_{26}{ }^{3-}, \mathrm{Mo}_{12} \mathrm{O}_{37}{ }^{2-}$, $\mathrm{H}_{7} \mathrm{Mo}_{24} \mathrm{O}_{78}{ }^{5-}, \mathrm{Mo}_{36} \mathrm{O}_{112}{ }^{8-}$ etc. have been reported in many recent publications. ${ }^{10-12}$

On account of the complexity of the relation of equilibrium between the polyanions or due to the experimental difficulty in early works, the conclusions of 
earlier workers seem to be overstrained and hence it was considered worthwhile to make a careful and precise study on the formation of molybdates as a function of $\mathrm{pH}$ by electrometric techniques, which have provided more conclusive evidence on the condensation process of vanadate, ${ }^{13}$ antimonite ${ }^{14}$ thiotungstate ${ }^{15}$ and tungstate anions. ${ }^{16}$ In an earlier publication ${ }^{17}$ Prasad and Gonçalves have reported the effect of $\mathrm{pH}$ change on composition of thorium molybdate. The results on formation of thallium molybdates as a function of $\mathrm{pH}$ are presented here.

\section{Experimental}

All the reagents including $\mathrm{TlNO}_{3}, \mathrm{Na}_{2} \mathrm{MoO}_{4} \cdot 2 \mathrm{H}_{2} \mathrm{O}$, $\mathrm{HNO}_{3}$ and ethanol of extra-pure grade were used, and their solutions were prepared with deionized distilled water. Concentration of sodium molybdate solutions was further verified by determining molybdenum with oxime as $\mathrm{MoO}_{2}\left(\mathrm{C}_{9} \mathrm{H}_{6} \mathrm{ON}\right)_{2}{ }^{18}$ The variations of $\mathrm{pH}$ of $\mathrm{Na}_{2} \mathrm{MoO}_{4}$ solutions were obtained by progressive additions of determined quantities of nitric acid. $\mathrm{pH}$ measurements were carried out using a Metrohm Herisau $\mathrm{pH}$-meter and Schott Gerate glass combined electrode. Stoichiometric points were obtained from the sharp inflections in the titration curves. The conductometric measurements were performed on a Metrohm conductometer. Conductivity values after correcting for dilution effect were plotted as a function of $\mathrm{mL}$ of titrant solution added and the end-points were judged from the breaks in titration curves. For each experiment, $25 \mathrm{~mL}$ of solution were taken in the cell and thermostated at $25 \pm 0.1^{\circ} \mathrm{C}$. The same concentrations of reactants were employed in both techniques for the sake of comparison of results. The potentiometric and conductometric titration curves are plotted together in the same figure for similar reasons and also for the sake of brevity. The titrations were performed both by direct and reverse methods at three different concentrations. The electrometric titration results on formation of different thallium molybdates are summarized in Table 1.

Analytical investigations on precipitates were also carried out with a view to substantiate the electrometric results. Different molybdates of thallium(I) were prepared by mixing stoichiometric amounts of thallium nitrate solution with the respective sodium molybdate solutions at specific $\mathrm{pH}$ levels 7.6, 5.5 and 4.1. The precipitates obtained were washed several times with aqueous $30 \%$ (v/v) ethanolic solution and dried in a vacuum dessicator for $36 \mathrm{~h}$. A known amount ( $c a .2 \mathrm{~g}$ ) of each of the above precipitates was dissolved in a minimum quantity of nitric acid and then analyzed quantitatively for molybdenum ${ }^{18}$ with dithiol and for thallium ${ }^{18}$ with thionalide. The results are summarized in Table 2.

Table 1. Summary of results of electrometric study on formation of thallium molybdates. Volume of titre solution taken in the cell $=25 \mathrm{~mL}$

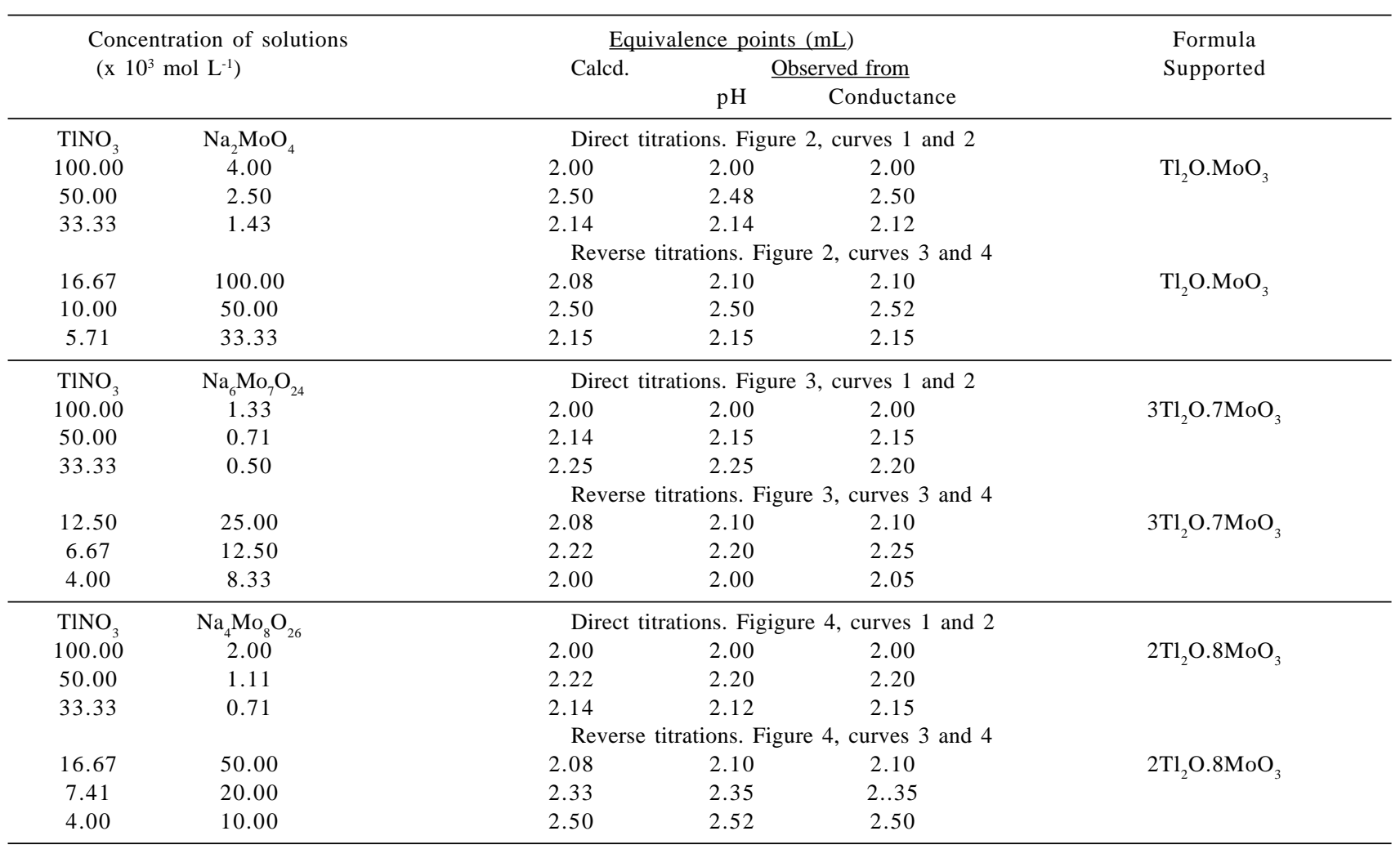


Table 2. Summary of analytical results of the precipitates of thallium molybdates

\begin{tabular}{|c|c|c|c|}
\hline \multirow{2}{*}{$\begin{array}{l}\text { Proposed formula } \\
\text { of the compound }\end{array}$} & \multirow[t]{2}{*}{ Mode of synthesis } & \multicolumn{2}{|c|}{ Analysis \%: Found (calculated) } \\
\hline & & $\mathrm{T} 1$ & Mo \\
\hline \multirow{3}{*}{$\mathrm{Tl}_{2} \mathrm{O}_{\mathrm{MoO}}$} & \multicolumn{2}{|c|}{ Analysis of the normal-molybdate precipitates. } & \\
\hline & Direct* & $71.79(71.88)$ & $16.83(16.87)$ \\
\hline & Reverse $^{*}$ & 71.95 & 16.90 \\
\hline \multirow{3}{*}{$3 \mathrm{Tl}_{2} \mathrm{O} .7 \mathrm{MoO}_{3}$} & \multicolumn{2}{|c|}{ Analysis of the para-molybdate precipitates. } & \\
\hline & Direct & $53.66(53.74)$ & $29.49(29.43)$ \\
\hline & Reverse & 53.81 & 29.39 \\
\hline \multirow{3}{*}{$2 \mathrm{Tl}_{2} \mathrm{O} .8 \mathrm{MoO}_{3}$} & \multicolumn{2}{|c|}{ Analysis of the octa-molybdate precipitates. } & \\
\hline & Direct & $40.78(40.85)$ & $38.41(38.36)$ \\
\hline & Reverse & 40.91 & 38.32 \\
\hline
\end{tabular}

${ }^{*}$ Direct - Thallium nitrate solution added to sodium molybdate solution. Reserve - Sodium molybdate solution added to mercuric nitrate solution.

\section{Results and Discussion}

When nitric acid is gradually added to $\mathrm{Na}_{2} \mathrm{MoO}_{4}$ solution, it changes to para-molybdate $\mathrm{Mo}_{7} \mathrm{O}_{24}{ }^{6-}$ and octamolybdate $\mathrm{Mo}_{8} \mathrm{O}_{26}{ }^{4-}$ polyanions around $\mathrm{pH} 5.5$ and 4.1, respectively. Figure 1 illustrates the curves of $\mathrm{pH}$ and conductometric titrations of $\mathrm{Na}_{2} \mathrm{MoO}_{4}$ solution with nitric acid. The titration curves of both the techniques show two inflections at $7 \mathrm{Mo}: 8 \mathrm{H}$ and $8 \mathrm{Mo}: 12 \mathrm{H}$ corresponding to the formation of the polyanions para- $\mathrm{Mo}_{7} \mathrm{O}_{24}{ }^{6-}$ and octa$\mathrm{Mo}_{8} \mathrm{O}_{26}{ }^{4-}$, respectively (see Figure 1, points A, B and A', $\left.\mathrm{B}^{\prime}\right)$. The results are similar to those obtained for the interaction of hydrochloric acid with sodium molybdate ${ }^{17}$ and are also in conformity with the results of the temperature-jump studies by Honing and Kustin ${ }^{19}$ and the Raman spectra studies by Ozeki et al. ${ }^{20}$ The stepwise condensation of $\mathrm{MoO}_{4}{ }^{2-}$ by gradual addition of nitric acid can be represented by the following equations: ${ }^{17}$

$$
\begin{aligned}
& 8 \mathrm{H}^{+}+7 \mathrm{MoO}_{4}{ }^{2-}=\mathrm{Mo}_{7} \mathrm{O}_{24}{ }^{6-}+4 \mathrm{H}_{2} \mathrm{O} \\
& 12 \mathrm{H}^{+}+8 \mathrm{MoO}_{4}{ }^{2-}=\mathrm{Mo}_{8} \mathrm{O}_{26}{ }^{4-}+6 \mathrm{H}_{2} \mathrm{O}
\end{aligned}
$$

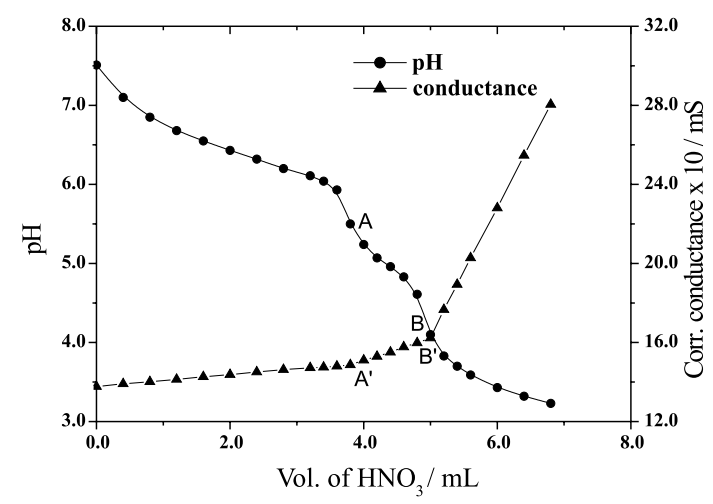

Figure 1. Potentiometric (curve 1) and conductometric (curve 2) titrations of acid-molybdate system. $25 \mathrm{~mL}$ of $1.33 \times 10^{-2} \mathrm{~mol} \mathrm{~L}^{-1}$ $\mathrm{Na}_{2} \mathrm{MoO}_{4}$ titrated with $1.00 \times 10^{-1} \mathrm{~mol} \mathrm{~L}^{-1} \mathrm{HNO}_{3}$ (stoichiometric points are $\mathrm{A}, \mathrm{B}$ and $\left.\mathrm{A}^{\prime}, \mathrm{B}^{\prime}\right)$.

\section{Thallium normal-molybdate}

Using different concentrations of $\mathrm{Na}_{2} \mathrm{MoO}_{4}(\mathrm{pH}$ 7.6) and thallium(I) nitrate ( $\mathrm{pH}$ 6.1) solutions, a series of potentiometric titrations was carried out. In direct titrations (Figure 2, curve 1), when $\mathrm{Na}_{2} \mathrm{MoO}_{4}$ solution was used as titrate, a gradual decrease in $\mathrm{pH}$ value was observed till at the stoichiometric end-point (the stage at which the
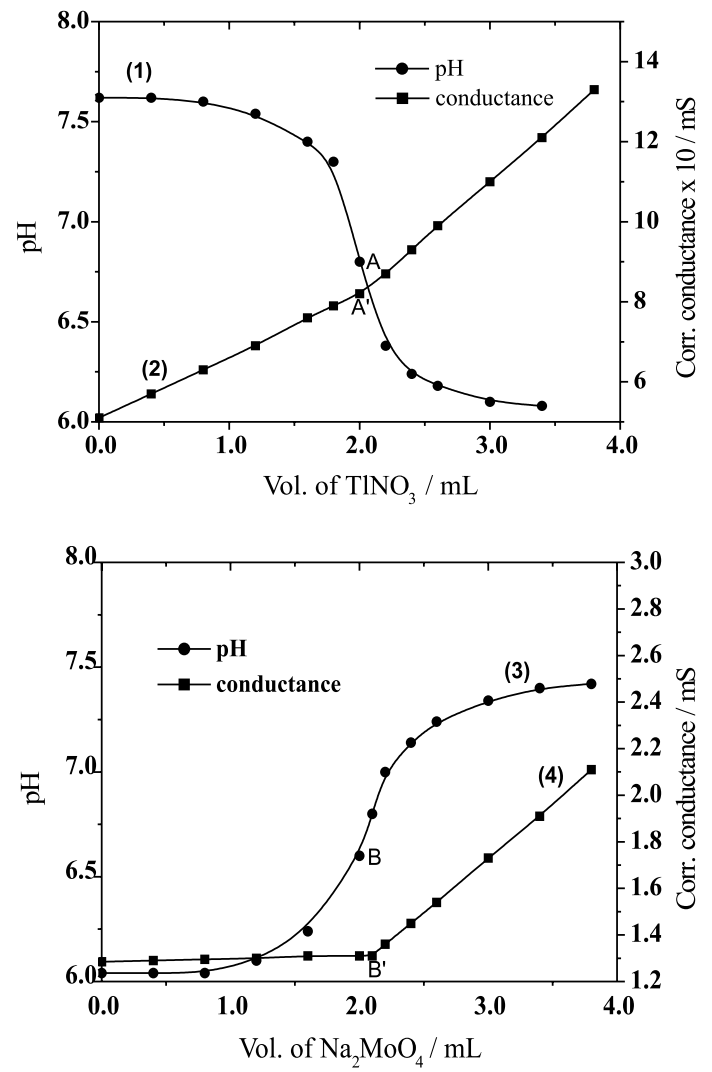

Figure 2. Normal-molybdate direct (1 and 2) and reverse (3 and 4) titrations. 1, 2: $25 \mathrm{~mL}$ of $4.00 \times 10^{-3} \mathrm{~mol} \mathrm{~L}^{-1} \mathrm{Na}_{2} \mathrm{MoO}_{4}$ titrated with $1.00 \times 10^{-1} \mathrm{~mol} \mathrm{~L}^{-1} \mathrm{TlNO}_{3} 3$, 4: $25 \mathrm{~mL}$ of $1.67 \times 10^{-2} \mathrm{~mol} \mathrm{~L}^{-1} \mathrm{TlNO}_{3}$ titrated with $1.00 \times 10^{-1} \mathrm{~mol} \mathrm{~L}^{-1} \mathrm{Na}_{2} \mathrm{MoO}_{4}$ (stoichiometric points: A, $\mathrm{B}$ and $\left.\mathrm{A}^{\prime}, \mathrm{B}^{\prime}\right)$. 
reaction ends if simple double decomposition takes place) a sharp fall in $\mathrm{pH}$ was observed (see point A in Figure 2) when the molar ratio of $\mathrm{Tl}^{+}: \mathrm{MoO}_{4}{ }^{2-}$ is $2: 1$ corresponding to the formation of thallium normal-molybdate, $\mathrm{Tl}_{2} \mathrm{O} . \mathrm{MoO}_{3}$, in the neighborhood of $\mathrm{pH}$ 6.8. In case of inverse titrations (Figure 2, curve 3), the $\mathrm{pH}$ at first gradually increases till in the vicinity of stoichiometric end-point when the last traces of thallium ions have been removed by precipitation, further addition of alkali molybdate causes a marked upward jump in $\mathrm{pH}$ and the inflection corresponds to the molar ratio for the formation of $\mathrm{Tl}_{2} \mathrm{O} . \mathrm{MoO}_{3}$ according to the reaction:

$$
2 \mathrm{TlNO}_{3}+\mathrm{Na}_{2} \mathrm{MoO}_{4}=\mathrm{Tl}_{2} \mathrm{O} \cdot \mathrm{MoO}_{3}+2 \mathrm{NaNO}_{3}
$$

Employing similar concentrations of the reactants, direct (Figure 2, curve 2) and reverse (Figure 2, curve 4) conductometric titrations between the solutions of thallium nitrate and sodium molybdate gave well-defined breaks at 2:1 molar ratio of $\mathrm{Tl}^{+}: \mathrm{MoO}_{4}{ }^{2-}$ confirming the formation of the same compound $\mathrm{Tl}_{2} \mathrm{O} . \mathrm{MoO}_{3}$ as indicated by the $\mathrm{pH}$ study.

\section{Thallium para-molybdate}

Sodium para-molybdate solution was prepared by addition of nitric acid to $\mathrm{Na}_{2} \mathrm{MoO}_{4}$ in molar ratio $8 \mathrm{H}: 7 \mathrm{Mo}$. Using different concentrations of sodium para-molybdate (pH 5.5) and thallium(I) nitrate ( $\mathrm{pH}$ 6.1) solutions, a series of potentiometric titrations was carried out. In direct titrations (Figure 3, curve 1), when the para-molybdate solution was used as titrate, a gradual change in $\mathrm{pH}$ value was observed till at the stoichiometric end-point a sharp upward jump in $\mathrm{pH}$ was observed when the molar ratio of $\mathrm{Tl}^{+}: \mathrm{Mo}_{7} \mathrm{O}_{24}{ }^{6-}$ is $6: 1$ corresponding to the formation of thallium para-molybdate, $3 \mathrm{Tl}_{2} \mathrm{O} .7 \mathrm{MoO}_{3}$, in the neighborhood of $\mathrm{pH}$ 5.9. In case of inverse titrations (Figure 3 , curve 3 ), when thallium nitrate solution was used as titrate, a gradual decrease in $\mathrm{pH}$ was observed till at the stoichiometric point a downward jump in $\mathrm{pH}$ was noted and the inflection corresponds to the molar ratio for formation of $3 \mathrm{Tl}_{2} \mathrm{O} .7 \mathrm{MoO}_{3}$. The formation of the paramolybdate can be represented as follows:

$6 \mathrm{TlNO}_{3}+\mathrm{Na}_{6} \mathrm{Mo}_{7} \mathrm{O}_{24}=3 \mathrm{Tl}_{2} \mathrm{O} .7 \mathrm{MoO}_{3}+6 \mathrm{NaNO}_{3}$

Employing similar concentrations of the reactants a series of direct (Figure 3, curve 2) and reverse (Figure 3, curve 4) conductometric titrations was performed between the solutions $\mathrm{TlNO}_{3}$ and $\mathrm{Na}_{6} \mathrm{Mo}_{7} \mathrm{O}_{24}$. The titration curves provide well-defined breaks at a point where the molar
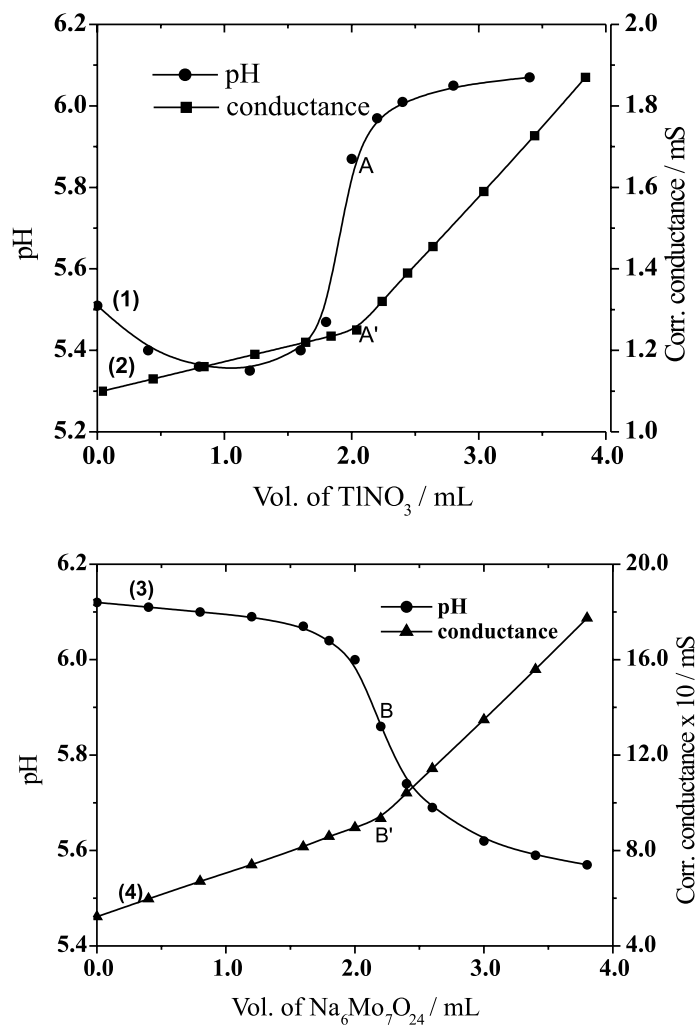

Figure 3. Para-molybdate direct (1 and 2) and reverse (3 and 4) titrations. 1, 2: $25 \mathrm{~mL}$ of $1.33 \times 10^{-3}$ mol. $\mathrm{L}^{-1} \mathrm{Na}_{6} \mathrm{Mo}_{7} \mathrm{O}_{24}$ titrated with $1.00 \times 10^{-1} \mathrm{~mol} \mathrm{~L}^{-1} \mathrm{TlNO}_{3} 3,4: 25 \mathrm{~mL}$ of $6.67 \times 10^{-3} \mathrm{~mol} \mathrm{~L}^{-1} \mathrm{TlNO}_{3}$ titrated with $1.25 \times 10^{-2} \mathrm{~mol} \mathrm{~L}^{-1} \mathrm{Na}_{6} \mathrm{Mo}_{7} \mathrm{O}_{24}$ (stoichiometric points: $\mathrm{A}^{3}$, $\mathrm{B}$ and $\left.\mathrm{A}^{\prime}, \mathrm{B}^{\prime}\right)$.

ratio of $\mathrm{Tl}^{+}: \mathrm{Mo}_{7} \mathrm{O}_{24}{ }^{6-}$ is 6:1 (Table 1), thus confirming formation of para-molybdate, as suggested by the $\mathrm{pH}$ study.

\section{Thallium octa-molybdate}

Sodium octa-molybdate solution was prepared by addition of nitric acid to $\mathrm{Na}_{2} \mathrm{MoO}_{4}$ in molar ratio $3 \mathrm{H}: 2 \mathrm{Mo}$. Using different concentrations of the solutions of $\mathrm{TlNO}_{3}$ and $\mathrm{Na}_{4} \mathrm{Mo}_{8} \mathrm{O}_{26}$, a series of potentiometric and conductometric titrations was carried out. The slope and nature of these titration curves (Figure 4) are similar to those of the para-molybdate. The curves provide well-defined inflections at molar ratio 4:1 of $\mathrm{Tl}^{+}: \mathrm{Mo}_{8} \mathrm{O}_{26}{ }^{4}$ (see points A, $\mathrm{B}$ and A', B' in Figure 4) corresponding to stoichiometry for formation of thallium octa-molybdate $2 \mathrm{Tl}_{2} \mathrm{O} .8 \mathrm{MoO}_{3}$ in the vicinity of $\mathrm{pH} 5.2$, according to the reaction:

$$
4 \mathrm{TlNO}_{3}+\mathrm{Na}_{4} \mathrm{Mo}_{8} \mathrm{O}_{26} \rightarrow 2 \mathrm{Tl}_{2} \mathrm{O} .8 \mathrm{MoO}_{3}+4 \mathrm{NaNO}_{3}
$$

It was noted that after each addition of the titrant, it takes a little time for the $\mathrm{pH}$ and conductance values to become steady. A thorough stirring in the neighborhood 

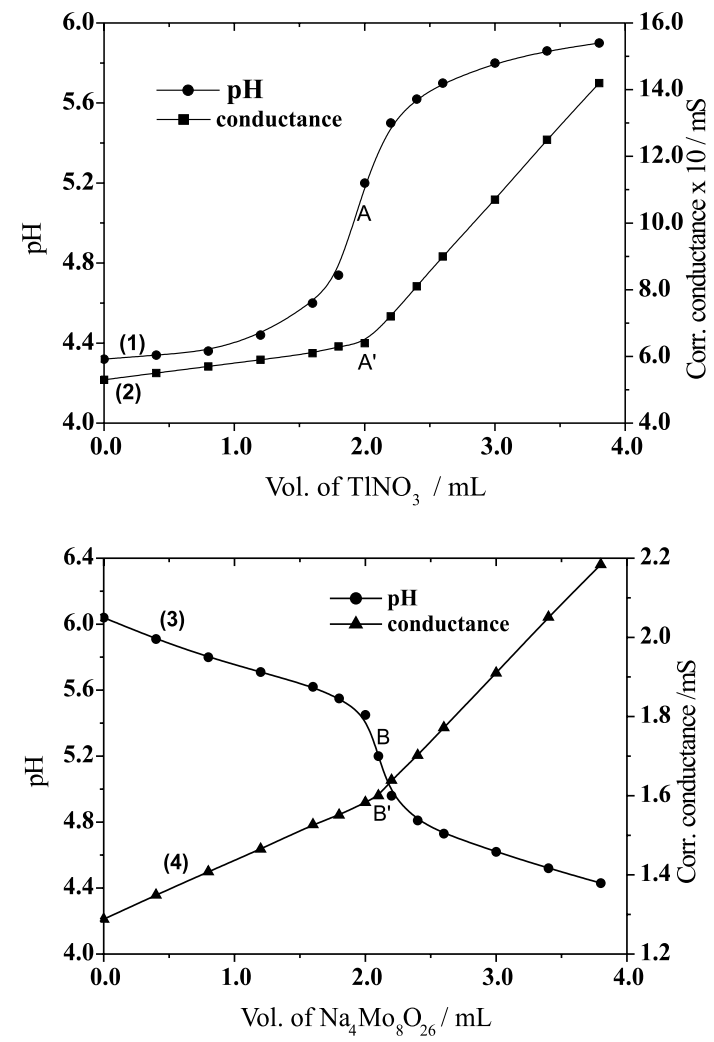

Figure 4. Octa-molybdate direct ( 1 and 2 ) and reverse ( 3 and 4) titrations. 1, 2: $25 \mathrm{~mL}$ of $2.00 \times 10^{-3} \mathrm{~mol} \mathrm{~L}^{-1} \mathrm{Na}_{4} \mathrm{Mo}_{8} \mathrm{O}_{26}$ titrated with $1.00 \times 10^{-1} \mathrm{~mol} \mathrm{~L}^{-1} \mathrm{TINO}_{3} 3$, 4: $25 \mathrm{~mL}$ of $1.67 \times 10^{-2} \mathrm{~mol} \mathrm{~L}^{-1} \mathrm{TINO}_{3}$ titrated with $2.00 \times 10^{-2} \mathrm{~mol} \mathrm{~L}^{-1} \mathrm{Na}_{4} \mathrm{Mo}_{8} \mathrm{O}_{26}$ (stoichiometric points: A, $\mathrm{B}$ and $\left.\mathrm{A}^{\prime}, \mathrm{B}^{\prime}\right)$.

of the equivalence point has a favorable effect. The presence of ethanol (30\%) improves the position of end-point and increase the magnitude of the jump in $\mathrm{pH}$ curves as it decreases the solubility of the precipitates formed and minimizes hydrolysis and adsorption. The results obtained were precise. The relative standard deviation of the results reported in Table 1 was $<1 \%$.

\section{Quantitative analysis of precipitates}

The results of the quantitative elemental analyses of the precipitates were used to calculate the proportions of the elements present in the compounds. From these proportions, the composition of the compounds was established which was found to be the same as obtained by the electrometric techniques (see Table 2).

The present electroanalytical investigations and the quantitative analysis of the precipitates confirm the formation and precipitation of three thallous molybdates viz. normal- $\mathrm{Tl}_{2} \mathrm{O} . \mathrm{MoO}_{3}$, para- $3 \mathrm{Tl}_{2} \mathrm{O} .7 \mathrm{MoO}_{3}$ and octa$2 \mathrm{Tl}_{2} \mathrm{O} .8 \mathrm{MoO}_{3}$ in the vicinity of $\mathrm{pH} 6.8,5.9$ and 5.2, respectively.
As the structure of these compounds are not known they are represented as double oxides, the manner which is usually adopted for such compounds. ${ }^{21,22}$

\section{Acknowledgement}

The authors are indebted to $\mathrm{CNPq}$ for financial assistance.

\section{References}

1. Haber, J.; The Role of Molybdenum in Catalysis; Climax Molybdenum Co.: London, 1981.

2. Simpson, C.H.; Amer. Paint. Coating J. 1992, 66.

3. Kopf-Maier, P.; Klopotke, T.; J. Cancer Res. Clin. Oncol. 1992, 118, 216.

4. Jander, G.; Jahr, K.F.; Henkesheshoven, W.; Z. Anorg. Chem. 1930, 194, 383.

5. Bye, J.; Ann. Chim. Fr. 1945, 20, 463; C. R. Acad. Sci., Paris. 1954, 238, 239; Bull. Soc. Chim. Fr. 1957, 1023.

6. Sasaki, Y.; Lindeqvist, I.; Sillen, L. G.; J. Inorg. Nucl. Chem. 1959, 9, 93.

7. Sasaki, Y.; Sillen, L.G.; Acta Chem. Scand. 1964, 18, 1014.

8. Sasaki, Y.; Sillen, L.G.; Ark. Khemi. 1968, 29, 253.

9. Aveston, J.; Anacker, E. W.; Johanson, J. S.; Inorg. Chem. 1964, 3, 735 .

10. Ozeki, T.; Adachi H.; Ikeda, S.; Bull. Chem. Soc. Jpn. 1996, 69,619 .

11. Ozeki, T.; Kinoshita, Y.; Adachi, H.; Bull. Chem. Soc. Jpn. 1994, 67, 1041

12. Pope, M. T. In Progress in Inorganic Chemistry; Lippard, S. J.; ed.; An Interscience Publication: New York, vol. 39, 1991.

13. Prasad, S.; Gonçalves, S.B.; Brito, J. B.; Catal. Today. 2000, 57, 339.

14. Prasad, S.; Bull Electrochem. 1990, 6, 163.

15. Prasad, S.; Can. J. Chem. 1981, 59, 563.

16. Prasad, S.; Quim. Nova. 1994, 17, 31.

17. Prasad, S.; Gonçalves, S.B.; J. Braz. Chem. Soc. 2000, 11, 199.

18. A. I. Vogel; A Textbook of Quantitative Inorganic Analysis, $3^{\text {rd }}$. ed., Longmans: London, 1962, p. 508; 793; 550.

19. Honing, D.S.; Kustin, M.; Inorg. Chem. 1972, 11, 65.

20. Ozeki, T.; Kihara, H.; Hikima, G.; Anal. Chem. 1987, 59, 945.

21. Standen, A.; Ex. ed.; Kirk-Othmer Encyclopedia of Chemical Technology, $2^{\text {nd }}$. ed., Interscience Publishers: New York, 1967, v. 13, p. 782.

22. Brauer, G., ed. In Handbook of Preparative Inorganic Chemistry, $2^{\text {nd }}$. ed., Academic Press: New York, 1965, v. 2, p. 1705.

Received: December 12, 2001

Published on the web: July 26, 2002 